\title{
PEMBENTUKAN JIWA ENTREPRENEURSHIP BAGI PARA ISTRI NELAYAN MELALUI PELATIHAN PEMBUATAN GREEBLE CHIPS
}

\author{
Anggia Sari Lubis*1, Debbi Chyntia Ovami, Ratna Sari Dewi ${ }^{3}$ \\ 1,2,3 Universitas Muslim Nusantara Al Washliyah; Jl Garu II No 93 \\ ${ }^{1}$ Program Studi Manajemen, ${ }^{2.3}$ Program Studi Akuntansi Fakultas Ekonomi, UMN Al Washliyah \\ e-mail: anggiasarilubis@gmail.com
}

\begin{abstract}
The concept of entrepreneurship is present to increase economic growth in Indonesia. Kuala Lama Village Serdang Bedagai is $60 \mathrm{Km}$ from Medan City or $8 \mathrm{Km}$ from Sei Rampah (the capital of Serdang Bedagai Regency). The main livelihoods of the population are as farmers and fishermen. Training materials include: brief lectures to motivate fisherman's wives, nature and characteristics of fresh green vegetables; how to processed the green vegetables into packaged food products named Greeble Chips. The expected target of this activity is to help improving the skills of fisherman wife in Kuala Lama Village, Pantai Cermin Subdistrict, in processing the green vegetables into a durable food packaging and have high selling value. The output of this activity is green vegetable processed products named Greeble Chips. The real result in this activity is to produce green processed products named green vegetable chips (greeble chips), business assistance, motivation and increasing skills and understanding of marketing strategy and simple financial report.
\end{abstract}

Keywords-Creation of Entrepreneurship Spirit, Greeble Chips

Abstrak
Konsep kewirausahaan hadir untuk meningkatkan pertumbuhan perekonomian di Indonesia. Desa Kuala Lama Kec. Pantai Cermin Serdang Bedagai berjarak 60 Km dari Kota Medan atau $8 \mathrm{Km}$ dari Sei Rampah (ibukota Kabupaten Serdang Bedagai). Mata pencaharian utama penduduk adalah sebagai petani dan nelayan. Materi pelatihan meliputi: ceramah singkat untuk memotivasi istri nelayan, Sifat dan karakteristik jenis sayuran hijau yang masih segar; mengolah sayuran hijau menjadi produk pangan kemasan yaitu Greeble Chips.Target yang diharapkan dari kegiatan Pengabdian ini adalah pengabdi dapat membantu meningkatkan keterampilan istri nelayan di Desa Kuala Lama Kecamatan Pantai Cermin dalam mengolah sayuran hijau menjadi pangan kemasan yang awet dan mempunyai nilai jual tinggi. Luaran dari kegiatan ini adalah produk olahan sayuran hijau yaitu Greeble Chips. Hasil nyata dalam kegiatan ini adalah menghasilkan produk olahan syauran hijau yaitu keripik sayuran hijau (greeble chips), pendampingan usaha, timbulnya motivasi dan meningkatnya keterampilan dan pemahaman strategi pemasaran dan laporan keuangan sederhana.

Kata kunci-Pembentukan Jiwa Entrepreneurship, Greeble Chips

\section{PENDAHULUAN}

Indonesia masih masuk ke dalam kategori negara berkembang karena belum mempunyai kondisi ekonomi dan sosial yang makmur, kebanyakan penduduknya miskin, pemikiran-pemikiran modern belum menyusup sampai ke desa-desa, dan kemajuan teknologi masih sangat jarang mampir sampai ke desa-desa, serta banyaknya pengangguran. Pendapatan masyarakat yang rendah dan tingkat populasi penduduk yang tinggi menjadi suatu permasalahan yang harus diatasi oleh pemerintah negara berkembang dalam upaya mensejahterakan rakyatnya. 
Pendapatan masyarakat yang rendah menyebabkan tidak mampunya mereka untuk meningkatkan kualitas sumber daya manusia seperti tidak mampu untuk memberikan pendidikan atau menyekolahkan anak-anak mereka. Hal tersebut menyebabkan kecerdasan generasi penerus bangsa tidak berkembang dan pada akhirnya akan menimbulkan kesenjangan ekonomi yang tajam antara orang yang berpenghasilan tinggi dan orang yang berpenghasilan rendah. Hal ini menyebabkan kemerosotan perekonomian di Negara Indonesia. Jika di biarkan keadaan perekonomian Negara Indonesia seperti itu terus maka semakin lama Negara akan semakin miskin dan terbelakang, serta berdampak pada keamanan nasional akan terganggu.

Konsep kewirausahaan hadir untuk meningkatkan pertumbuhan perekonomian di Indonesia. Para entrepreneur (wirausahawan) merupakan agen perubahan ekonomi yang strategis yang dapat mengubah keadaan perekonomian Indonesia. Desa Kuala Lama Kec.Pantai Cermin Serdang Bedagai berjarak $60 \mathrm{Km}$ dari Kota Medan atau 8 Km dari Sei Rampah (ibukota Kabupaten Serdang Bedagai). Mata pencarian dari penduduk Desa ini pada umumnya adalah Petani, dengan hasil pertanian yang sudah sangat memuaskan. Selain sebagai petani, penduduk di desa ini juga sebagian besar adalah menjadi nelayan, mengingat desa ini berada di dekat laut dan pantai.

Para nelayan di desa ini tentunya tidak memiliki pendapatan yang pasti setiap harinya mengingat profesi sebagai nelayan sangat bergantung pada keramahan alam dan unsur keberuntungan. Selain itu faktor penting lain yang mempengaruhi pendapatan nelayan adalah harga bahan bakar minyak (BBM). Dengan adanya kenaikan harga BBM akhir-akhir ini akan memberatkan para nelayan, sehingga sebagian dari mereka tidak melaut. Karena hasil yang diperoleh (jumlah tangkapan ikan) tidak sesuai dengan biaya (jumlah harga solar) yang dikeluarkan. Hasil tangkapan tersebut dijual dalam keadaan segar/langsung dari laut dengan harga yang sering tidak menentu/fluktuasi harga.

Selain itu, ketika nelayan tidak melaut maka mereka tidak mendapatkan penghasilan, sementara kebutuhan keluarga terus berjalan. Dalam kondisi seperti ini peran seorang wanita (istri) sangat diperlukan untuk membantu memenuhi kebutuhan keluarga, dan diperlukan alternatifalternatif untuk mengatasi kesulitan ekonomi keluarga dalam memenuhi kebutuhan hidup. Wanita secara umum memiliki multi peran yang menghendaki adanya keselarasan dalam melaksanakan tugasnya. Di negara yang sedang berkembang peran wanita biasanya berkaitan dengan mengasuh dan membesarkan anak serta memelihara kesehatan dan kesejahteraan seluruh anggota keluarga. Peran selanjtunya berkaitan dengan kegiatan di luar rumah bagi wanita dan pria untuk tujuan mendapat penghasilan (uang). Wanita juga harus mampu menangani masalah sosial dan ekonomi terutama dari sisi peningkatan pendapatan keluarga. Fungsi atau peranan wanita ini perlu diperhatikan dengan berbagai perhatian, pembinaan dan pengembangan.

Berdasarkan kondisi di atas maka perlu diadakan upaya pembentukan mindset jiwa entrepreneurship bagi para istri nelayan, agar muncul kesadaran akan pentingnya mengungkap potensi yang ada di dalam diri untuk menghasilkan sesuatu yang bernilai dan dapat menambah pendapatan keluara di Desa Kuala Lama Kecamatan Pantai Cermin Kabupaten Serdang Bedagai. Salah satu upaya yang dapat dilakukan adalah memanfaatkan hasil pertanian Desa setempat yang dala hal ini adalah sayuran hijau yang dapat diolah menjadi penganan yang bernilai jual. Konsep dasarnya adalah memanfaatkan sayuran-sayuran hijau yang cenderung sangat mudah untuk ditemukan di sekitar desa seperti sawi hijau, daun singkong, daun kemangi, kangkung dan bayam yang diolah menjadi keripik renyah (Chips) yang akan menjadi ciri khas Desa Kuala Lama Pantai Cermin untuk dapat dijual kepada wisatawan yang datang, ataupun dipasarkan di seluruh kecamatan yang ada di Kabupaten Serdang Bedagai. Produk yang akan dihasilkan adalah Greeble Chips (Green Vegetable Chips) ataupun keripik sayuran hijau. Dengan demikian selain memberikan keuntungan dari segi peningkatan pengetahuan dan keterampilan sumber daya manusia, juga sekaligus memberikan keuntungan secara ekonomi, dengan demikian dapat meningkatkan pendapatan masyarakat. Dengan adanya program pengabdian kepada masyarakat ini diharapkan konsep ekonomi kerakyatan dapat berjalan dengan efektif, dan masyarakat dapat meningkatkan kemampuan dan kemandirian untuk mengelola sumber daya alam agar taraf hidup masyrakat dapat meningkat ke arah yang lebih baik lagi.

Solusi yang dapat diberikan dari permasalahan prioritas masyarakat Desa Kuala Lama Kecamatan Pantai Cermin Kabupaten Serdang Bedagai antara lain: 
1. Memberikan ceramah singkat yang bersifat motivasional mengenai pentingnya berwirausaha yang nantinya akan membangkitkan semangat para istri nelayan untuk mau memanfaatkan kemampuan yang ada pada dirinya, sehingga pada akhirnya dapat membantu perekonomian keluarga. Karena pada dasarnya di dalam diri setiap manusia pasti diberkahi oleh kemampuan dan kreativitas. Dan tugas dari manusia tersebut untuk menyadari, memanfaatkan, dan mengembangkan kemampuan yang ada di dalam dirinya, menjadi sebuah kreativitas. Dari kreativitas inilah seorang manusia bisa berinovasi, menciptakan produk yang benilai jual, sehingga memperoleh kemandirian ekonomi.

2. Masyarakat diberikan ceramah singkat mengenai jenis-jenis sayuran hijau yang sehat dan bermanfaat bagi tubuh yang dapat diolah menjadi produk yang enak, gampang dikonsumsi dan bernilai.

3. Masyarakat diberikan pengetahuan atas alternatif penggunaan perlengkapan dan peralatan yang sederhana untuk dapat memproduksi olahan sayuran hijau.

4. Masyarakat diberikan pelatihan mengenai teknik pembuatan produk dari sayuran hijau yang benilai jual, bergizi, higienis dan berkualitas, sehingga dapat meningkatkan pendapatan dan taraf hidup mereka.

Target yang diharapkan dari kegiatan Pengabdian Masyarakat ini adalah dapat ,menumbuhkan minat untuk berwirausahan di kalangan istri nelayan serta membantu meningkatkan keterampilan istri nelayan di Desa Kuala Lama Kecamatan Pantai Cermin Kabupaten Serdang Bedagai dalam mengolah sayuran hijau menjadi penganan yang awet, bergizi dan mempunyai nilai jual tinggi. Dengan demikian selain memberikan keuntungan dari segi peningkatan pengetahuan dan keterampilan sumber daya manusia, juga sekaligus memberikan keuntungan secara ekonomi. Secara lebih spesifik, target yang ingin dicapai adalah sebagai berikut

1. Menumbuhkan minat untuk berwirausaha dikalangan istri nelayan serta meningkatkan motivasi istri nelayan untuk membantu perekonomian keluarga dengan memanfaatkan sumber daya alam berupa sayuran hijau untuk diolah menjadi produk yang bernilai jual, awet, bergizi dan berkualitas.

2. Meningkatkan pengetahuan istri nelayan dalam hal jenis dan karakteristik sayuran hijau yang dapat diolah menjadi penganan kemasan.

3. Meningkatkan pemahaman istri nelayan dalam memanfaatkan perlengkapan dan peralatan sederhana yang mereka miliki untuk dapat mengolah sayuran hijau menjadi produk yang bernilai jual, awet, bergizi dan berkualitas.

4. Meningkatkan keterampilan istri nelayan dalam mengolah sayuran hijau menjadi penganan kemasan yang awet, bergizi, dan bernilai jual tinggi yaitu Greeble Chips (Green Vegetable Chips) ataupun keripik sayuran hijau, sehingga dapat meningkatkan pendapatan istri nelayan dalam mencapai taraf kehidupan yang lebih baik.

Luaran dari kegiatan Pengabdian Masyarakat ini adalah produk olahan sayuran hijau yaitu Greeble Chips (Green Vegetable Chips) ataupun keripik sayuran hijau. Bila target dan luaran tersebut tercapai, maka istri nelayan di Desa Kuala Lama Kecamatan Pantai Cermin Kabupaten Serdang Bedagai dapat memiliki pengetahuan dan keterampilan dalam mengolah penganan kemasan dari sayuran hijau yang lebih baik dari sebelum diberi pelatihan, serta dapat meningkatkan pendapatan keluarga dengan cara memasarkan hasil olahan tersebut.

Dengan meningkatnya penghasilan keluarga, maka kesejahteraan masyarakatnya juga meningkat, dan penerapan sistem ekonomi kerakyatan akan berjalan dengan baik. Peningkatan kesejahteraan masyarakat akan diikuti dengan peningkatan kesempatan generasi muda dalam melanjutkan pendidikan. Semakin tinggi tingkat pendidikan generasi muda, maka semakin berkualitas Sumber Daya Manusia. Dengan kualitas Sumber Daya Manusia (SDM) yang baik akan mampu mengembangkan daerahnya menjadi lebih baik dengan memanfaatkan potensi lokal yang ada menjadi keunggulan lokal di daerahnya. 


\section{METODE}

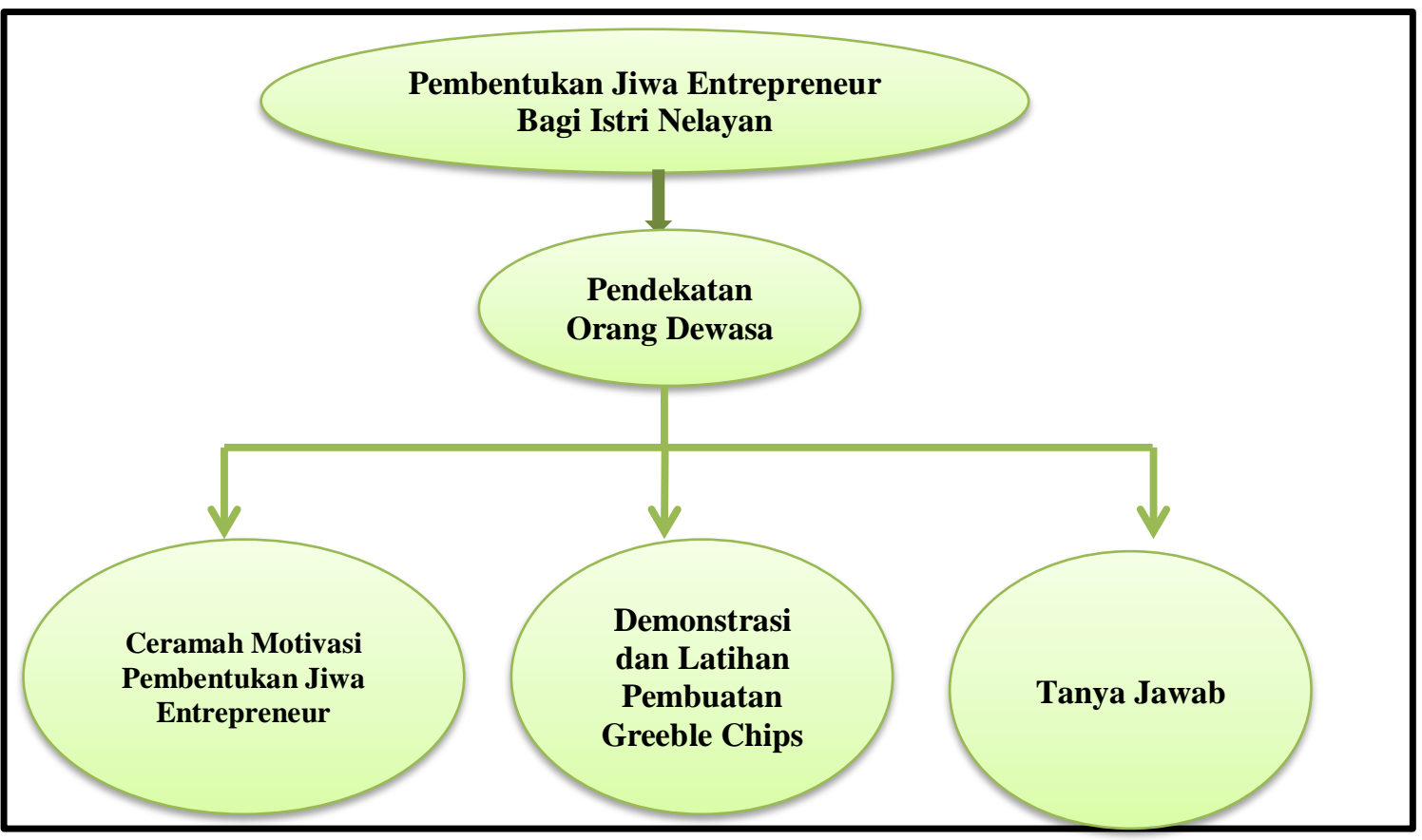

Gambar 2.1 Metode Pelaksanaan Pengabdian Masyarakat

Kegiatan ini akan dilakukan di balai Desa Kuala Lama Kecamatan Pantai Cermin Kabupaten Serdang Bedagai. Dalam kegiatan ini akan melibatkan 30 istri nelayan yang tidak mempunyai pekerjaan/menganggur. Diharapkan peserta mempunyai kemauan dan kemampuan dalam mengikuti pelatihan serta meiliki motivasi dalam berwirausaha untuk memasarkan penganan kemasan nantinya.

Kegiatan ini akan dilaksanakan dengan metode pelatihan yang menerapkan konsep pendekatan orang dewasa. Pendekatan orang dewasa (andragogi) adalah seni dan pengetahuan mengajar orang dewasa. Pertumbuan orang dewasa dimulai pertengahan masa remaja (adolescence) sampai dewasa, di mana setiap individu tidak hanya memiliki kecenderungan tumbuh kearah menggerakkan diri sendiri tetapi secara aktual dia menginginkan orang lain memandang dirinya sebagai pribadi yang mandiri yang memiliki identitas diri. Dengan begitu orang dewasa tidak menginginkan orang memandangnya apalagi memperlakukan dirinya seperti anak-anak. Dia mengharapkan pengakuan orang lain akan otonomi dirinya, dan dijamin ketentramannya untuk menjaga identitas dirinya dengan penolakan dan ketidaksenangan akansetiap usaha orang lain untuk menekan, memaksa, dan manipulasi tingkah laku yang ditujukan terhadap dirinya. Tidak seperti anak-anak yang beberapa tingkatan masih menjadi objek pengawasan, pengendalian orang lain yaitu pengawasan dan pengendalian orang dewasa yang berada di sekeliling, terhadap dirinya.

Dalam kegiatan pendidikan atau belajar, orang dewasa bukan lagi menjadi obyek sosialisasi yang seolah-olah dibentuk dan dipengaruhi untuk menyesuaikan dirinya dengan keinginan memegang otoritas di atas dirinya sendiri, akan tetapi tujuan kegiatan belajar atau pendidikan orang dewasa tentunya lebih mengarah kepada pencapaian pemantapan identitas dirinya sendiri untuk menjadi dirinya sendiri.

Dalam kegiatan pengabdian masyarakat ini pelatihan yang dikembangkan telah diatur sedemikian rupa sesuai dengan prinsip-prinsip pendekatan orang dewasa yang terdiri dari:

a) Pengaturan lingkungan fisik yang dengan mengatur dan menata ruangan, pengaturan meja, kursi dan peralatan lainnya yang memungkinkan terjadinya interaksi sosial diantara peserta dan pengabdi. 
b) Pengaturan Lingkungan Sosial dan Psikologi yaitu dengan iklim psikologis yang baik sehingga peserta merasa diterima, dihargai dan didukung. Para pengabdi dalam kegiatan ini lebih bersifat membantu dan mendukung, mengembangkan suasana bersahabat, informal dan santai.

serta disesuaikan dengan kondisi, potensi dan karakteristik para istri nelayan yang akan menjadi sasaran. Secara lebih rinci metode kegiatan ini adalah sebagai berikut :

a) Menghimpun peserta pelatihan (istri nelayan), yang menjadi sasaran kegiatan. Dalam menghimpun peserta pelatihan tim pengabdi bekerja sama dengan Kepala Desa setempat. Di tahap awal meminta izin secara resmi dengan membawa surat izin resmi dari Lembaga Penelitian dan Pengabdian Masyarakat (LP2M) UMN-AW kepada Kepala Desa Kuala Lama. Setelah memperoleh izin, tim pengabdi yang tetap didampingi Kepala Desa Kuala Lama mengunjungi perumahan warga sambil mengundang para istri nelayan untuk menjadi peserta pada kegiatan Pengabdian Masyarakat yang akan kami lakukan.

b) Merancang materi ceramah singkat untuk memotivasi para istri nelayan, serta ceramah singkat untuk pemahaman jenis-jenis sayuran hijau dan pemanfaatan peralatan dan perlengkapan sederhana. Pada saat melaksanakan ceramah singkat tim pengabdi juga melakukan ice breaking kepada peserta untuk mencegah timbulnya rasa jenuh peserta. Penjelasan yang diberikan juga dirancang seefektif mungkin agar mudah dipahami

c) Membuat modul-modul pelatihan sesuai dengan materi yang akan diberikan, meliputi: mengolah sayuran hijau menjadi produk pangan kemasan yaitu Greeble Chips (Green Vegetable Chips) ataupun keripik sayuran hijau, cara mengemas produk pangan kemasan, serta teknik pemasaran pangan kemasan. Selain itu juga diberikan materi sederhana mengenai teknik pemasaran yag efektif pada saat ini dengan memanfaatkan teknologi internet dan media sosia, serta materi mengenai pembuatan perencanaan keuangan dan penyusunan laporan keuangan sederhana. Modul dirancang sedemikian rupa, dan disesuaikan dengan tingkat pendidikan, pemahaman dan karakteristik peserta pelatihan, dengan bahasa yang mudah dipahami oleh peserta didik, serta menarik.

d) Melakukan pelatihan yang dipusatkan di balai Desa Kuala Lama Kecamatan Pantai Cermin Kabupaten Serdang Bedagai.

Metode yang digunakan dalam pelatihan ini adalah sebagai berikut :

a) Ceramah singkat, digunakan untuk menyampaikan sejumlah informasi, dibantu dengan modul dan media belajar keterampilan. Ceramah bersifat motivasional dengan terlebih dahulu menumbuhkan semangat bagi para istri nelayan untuk dapat mengungkapkan kreativitas yang terdapat di dalam dirinya, yang mana kreativitas tersebut dapat dimanfaatkan untuk menghasilkan produk-produk khas dari Desa Kuala Lama untuk dipasarkan sehingga dapat membantu perekonomian keluarga. Dilanjutkan dengan memberikan materi tentang pembentukan spirit jiwa entrepreneurship. Pada materi ini, peserta akan diberikan motivasi mengenai pentingnya berwirausaha agar dapat memperoleh kemandirian dalam perekonomian dan meningkatkan kesejahteraan keluarga. Materi selanjutnya adalah pemahaman mengenai pemanfaatan local greatness yang ada di Desa Kuala Lama yang salah satunya adalah sayuran hijau yang banyak ditemukan bahkan di pekarangan rumah warga. Sehingga untuk bahan baku utama pembuatan produk ini dapat ditanam sendiri dan tidak perlu mengeluarkan biaya.Sayuran hijau apa saja yang dapat dijadikan bahan utama dalam membuat produk ini juga dijelaskan kepada para peserta, sampai kepada bahan baku pendukung dan proses pembuatannya. 


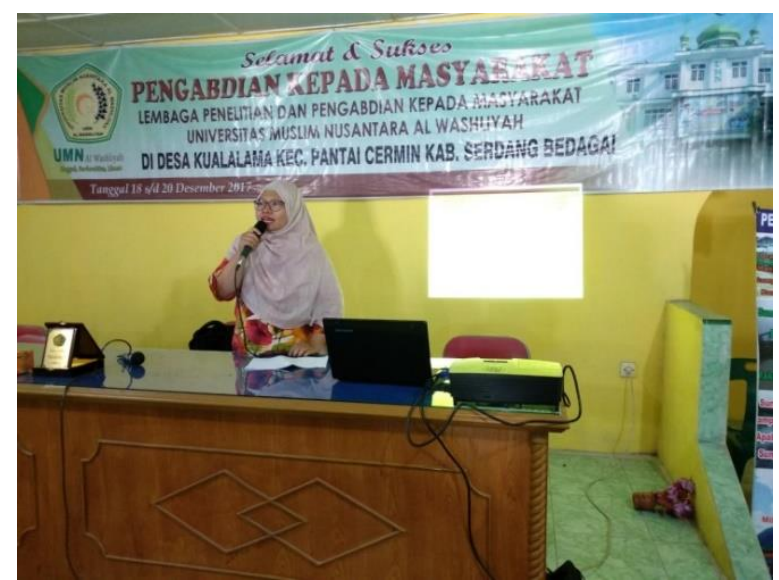

Gambar 2.2. Pemaparan Materi Bagi Peserta

b) Tanya jawab, digunakan selama proses pelatihan, adalah atau bahkan setelah proses tersebut.

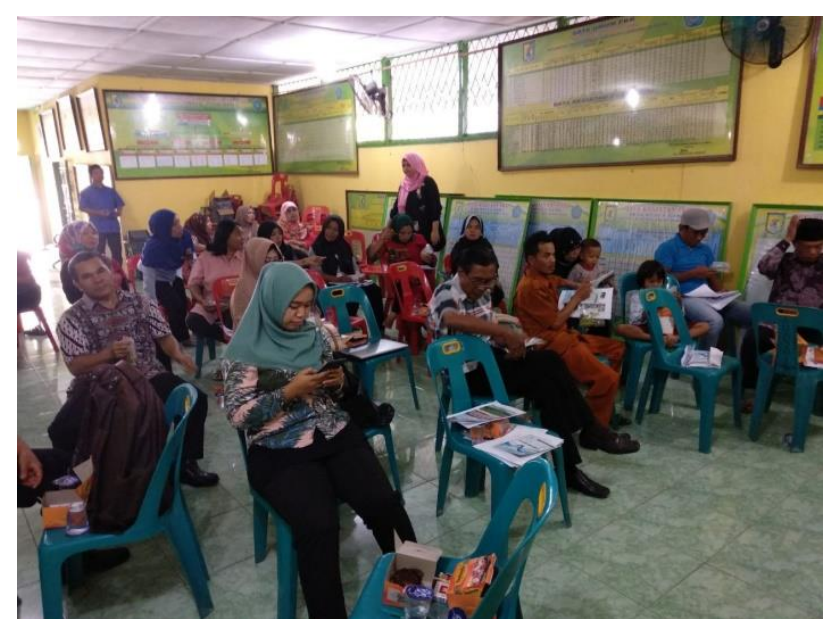

Gambar 2.3 Suasana Tanya Jawab Saat Pelatihan

c) Demontrasi dan latihan, digunakan untuk memperlihatkan langkah kerja setiap materi yang diberikan.

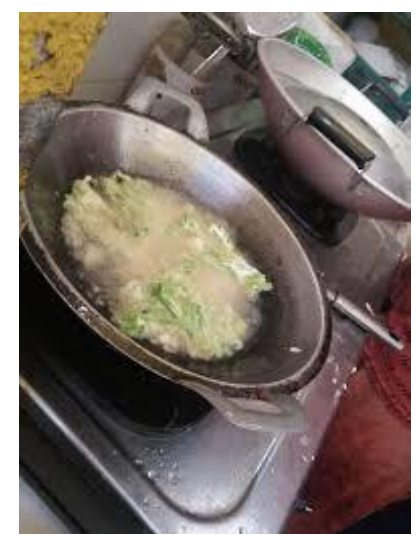

Gambar 2.4. Praktek Pembuata Greeble Chips 


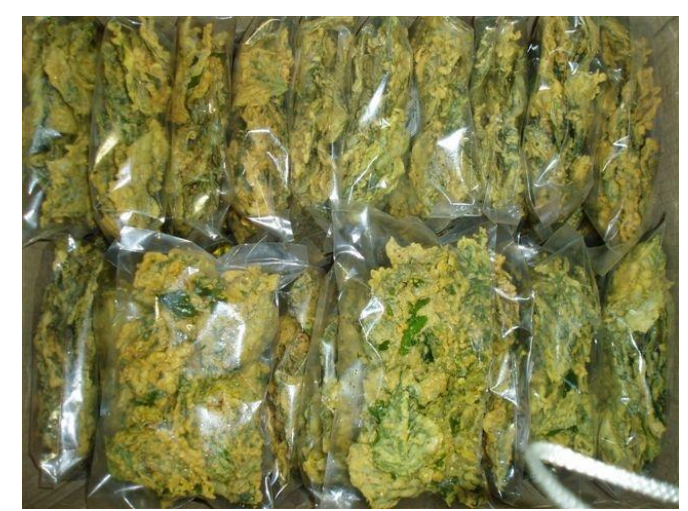

Gambar 2.2. Greeble Chips yang Siap Dipasarkan

\section{Bahan-Bahan Pembuatan Greeble Chips:}
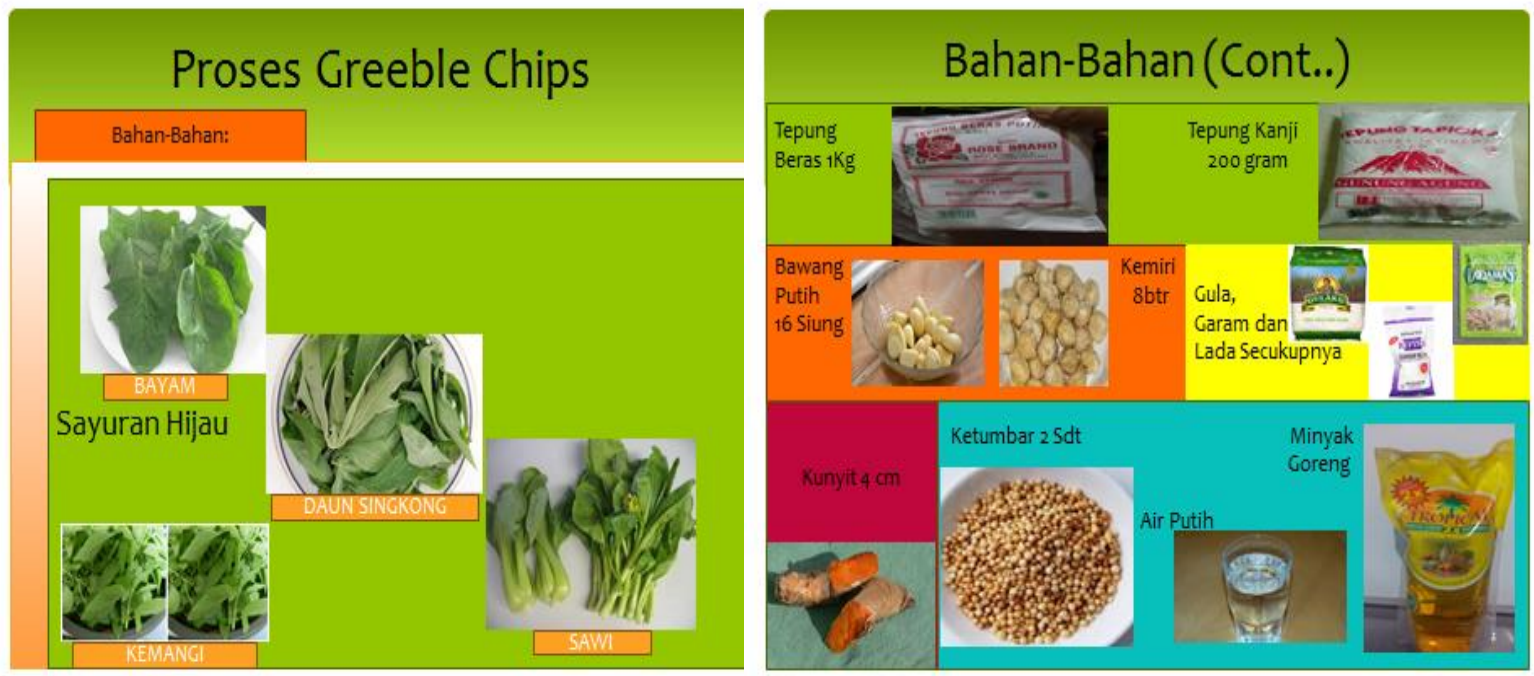

Gambar 2.3. Bahan-Bahan Greeble Chips

\section{Langkah-Langkah Pembuatan Greeble Chips}

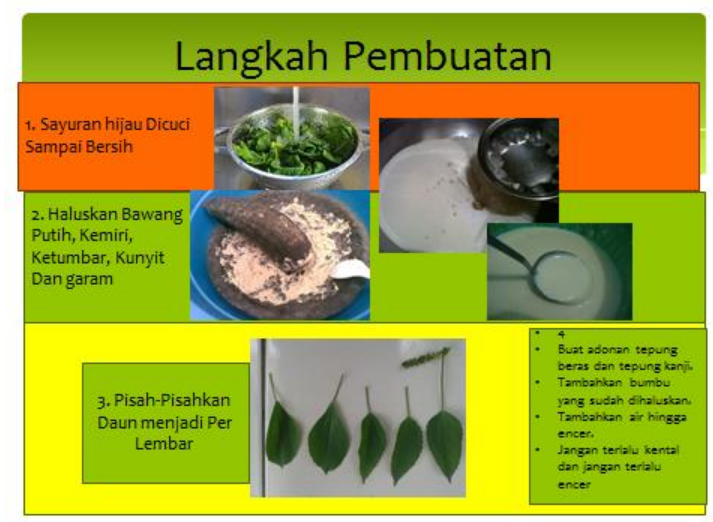

Gambar 2.4. Proses Pembuatan Greeble Chips 


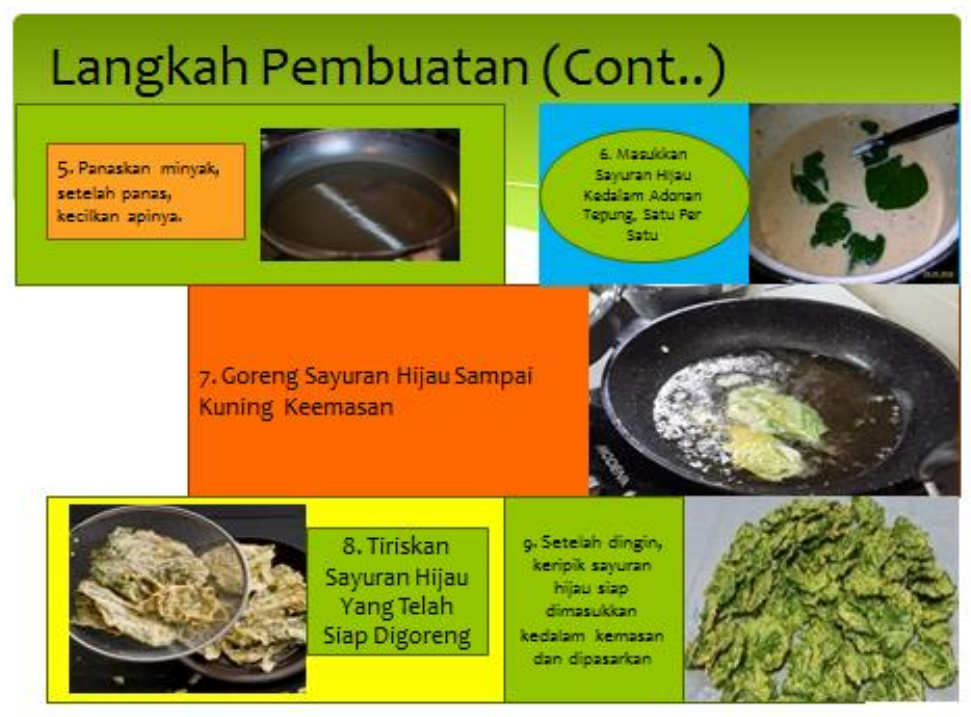

d) Peserta melakukan praktek sendiri cara mengolah dan mengemas produk hasil olahan sayuran hijau, dengan dipandu dan dibimbing oleh tim pengabdian masyarakat.

\section{HASIL DAN PEMBAHASAN}

Sesuai dengan rencana yang telah dilaksanakan maka kegiatan Pengabdian sejauh ini sudah mencapai $100 \%$, dimulai dari persiapan : pengadaan sekaligus penggandaan modul, pengadaan alat dan bahan, sosialisasi program, penentuan lokasi, waktu dan tempat kegiatan, kegiatan inti yakni pemberdayaan istri-istri nelayan dalam hal pembuatan keripik sayuran hijau (greeble chips) diikuti secara antusias oleh ibu-ibu nelayan yang ada di lokasi pengabdian hal ini dibuktikan dengan diedarkan undangan yang berjumlah 25 buah dan ternyata yang menghadiri undangan tersebut lebih dari jumlah undangan yang diedarkan.

Dalam pelaksanaan program kegiatan pengabdian yakni pembuatan keripik sayuran hijau (greeble chips) ternyata 3 orang diantara ibu-ibu yang datang itu sudah pernah mengikuti pelatihan serupa sehingga hal ini memudahkan kami dalam pelaksanaan pembuatan abon. Adapun yang menjadi hasil nyata dalam kegiatan ini adalah sebagai berikut:

A. Menghasilkan Produk Olahan Syauran Hijau yaitu keripik sayuran hijau (greeble chips).

Produk yang sudah dihasilkan adalah keripik sayuran hijau (greeble chips) dimana Pelatihan ini dibimbing oleh ketua dan anggota dalam pengabdian masyarakat ini. Dimulai dari pemaparan bahan baku yang digunakan, proses pembuatan, serta tips dan trik agar hasil olahan memiliki hasil yang terbaik dari segi rasa, kualitas serta bergizi dan tahan lama.

B. Pendampingan usaha

Pendampingan pengolahan sayuran hijau menjadi olahan keripik sayuran hijau (greeble chips) dilakukan di Balai Desa Kuala Lama, Pantai Cermin Kabupaten Serdang Bedagai. Bahkan juga dilakukan komunikasi melalui telepon, sehingga permasalahan usaha produk keripik sayuran hijau (greeble chips) dapat berjalan lancar. Pengabdian pada masyarakat ini dilakukan sampai tuntas sehingga bisa memberikan manfaat yang besar bagi masyarakat khususnya para istri nelayan di Desa Kuala Lama. Komunikasi antara tim pelaksana dengan peserta pengabdian masyarakat ini juga dapat dilakukan melalui media telepon genggam, (telepon, sms dan whatsapp) jika para peserta merasa perlu adanya bimbingan lebih lanjut mengenai produk keripik sayuran hijau (greeble chips) ini. Selain itu, rencana pada tahapan selanjutnya adalah merancang desain kemasan keripik sayuran hijau (greeble chips) agar menarik bagi konsumen, serta merealisasikan sistem pemasaran secara online untuk memperluas area pemasaran dengan memanfaatkan media sosial.

Rencana berikutnya adalah menjalin pola kemitraan antara para istri pembuat keripik sayuran hijau (greeble chips) dengan Dinas Perdagangan dan Perindustrian Kabupaten Serdang Bedagai untuk menciptakan iklim usaha yang kondusif, menumbuh kembangkan industri kecil dan 
menengah di Desa Kuala Lama. Dengan demikian diharapkan produk-produk yang dihasilkan para istri nelayan ini bisa diikutsertakan dalam kegiatan pameran industri kecil yang diadakan pada event-event tertentu di Serdang Bedagai.

C. Timbulnya Motivasi dan Meningkatnya Keterampilan

Pada saat kegiatan pengabdian masyarakat ini, sudah mulai terlihat adanya motivasi dari peserta dalam hal ini para istri nelayan untuk mengungkapkan kreativitas yang ada pada diri masing-masing peserta untuk berkontribusi atas peningkatan pendapatan keluarga. Salah satunya adalah keterampilan memasak yang tentunya sudah dimiliki para ibu-ibu pada umumnya. Dan dengan kegiatan ini para peserta memiliki pengetahuan bahwa sayuran hijau yang ditanam di sekitar rumah juga bisa memiliki nilai jual yang lebih tinggi apabila diolah dengan baik dan kreatif

D. Pemahaman Strategi Pemasaran dan Laporan Keuangan Sederhana

Para peserta kegiatan memiliki pemahaman mengenai strategi pemasaran hasil produk secara sederhana, pengelolaan usaha kecil, pengembangan pangsa pasar dan strategi untuk meningkatkan pendapatan juga menjadi prioritas. Materi ini diharapkan dapat menciptakan efektivitas kinerja untuk mencapai keuntungan kompetitif dengan biaya lebih rendah dan pelayanan . Peserta juga diberikan materi untuk menyusun laporan keuangan sederhana serta pemahaman untuk memisahkan keuangan pribadi dengan keuangan usaha agar pencapaian keuntungan lebih optimal.

Tahapan pelaksanaan pengabdian yang sudah dilakukan sampai saat ini adalah pada tahapan pelatihan dalam pemanfaatan sayuran hijau. Hasil yang diharapkan pada tahap ini adalah para istri nelayan memiliki motivasi untuk berkreasi dalam meningkatkan pendapatan keluarga dengan mengolah sayuran hijau menjadi olahan keripik sayuran hijau (greeble chips) yang memiliki nilai jual, enak, awet dan bergizi.Rencana pada tahapan selanjutnya adalah pendampingan para istri nelayan dalam merancang desain kemasan keripik sayuran hijau (greeble chips) agar menarik bagi konsumen, serta menjalankan sistem pemasaran secara online untuk memperluas area pemasaran dengan memanfaatkan media sosial.

Rencana selanjutnya adalah menjalin pola kemitraan antara para istri pembuat keripik sayuran hijau (greeble chips) dengan Dinas Perdagangan dan Perindustrian Kabupaten Serdang Bedagai untuk menciptakan iklim usaha yang kondusif, menumbuh kembangkan industri kecil dan menengah di Desa Kuala Lama. Dengan demikian diharapkan produk-produk yang dihasilkan para istri nelayan ini bisa diikutsertakan dalam kegiatan pameran industri kecil yang diadakan pada event-event tertentu di Serdang Bedagai.

\section{KESIMPULAN}

Dengan adanya program kegiatan pengabdian masyarakat dalam hal ini pembuatan keripik sayuran hijau (greeble chips), masyarakat dalam hal ini ibu-ibu nelayan mendapatkan pengalaman , pengetahuan serta keterampilan, dan seluruh kegiatan berhasil dengan baik tanpa ada hambatan.

\section{SARAN}

Kegiatan-kegiatan peningkatan keterampilan seperti yang dilakukan dalam program pengabdian masyarakat ini perlu lebih sering untuk diadakan. Sehingga dapat menambah wawasan dan pengetahuan serta inisiatif ibu-ibu nelayan untuk lebih terampil dengan tujuan membantu menopang ekonomi mereka. Selain itu pemerintah setempat sebaiknya memberikan perhatian lebih bagi masyarakat agar lebih produktif dan memiliki kesadaran untuk berwirausaha agar memiliki kemandirian dalam hal perekonomian keluarga.

\section{UCAPAN TERIMA KASIH}

Selama pelaksanaan pengabdian masyarakat ini, penulis telah banyak dibantu oleh berbagai pihak. Dalam kesempatan ini penulis ingin mengucapkan banyak terima kasih kepada : 
1. Bapak H. Hardi Mulyono, SE, M.AP selaku Rektor Universitas Muslim Nusantara AlWashliyah Medan.

2. Bapak Drs.Firmansyah, M.Si selaku Wakil Rektor I Universitas Muslim Nusantara AlWashliyah Medan.

3. Ibu Sriwardany,SE,M.Si selaku Wakil Rektor II Universitas Muslim Nusantara AlWashliyah Medan.

4. Bapak H. Milhan, MA selaku Wakil Rektor III Universitas Muslim Nusantara AlWashliyah Medan.

5. Ibu Nelvitia Purba, SH, M.Hum selaku ketua LP2M Universitas Muslim Nusantara AlWashliyah Medan.

6. Ibu Shita Tiara SE., Ak., M.Si selaku Dekan Fakultas Ekonomi Universitas Muslim Nusantara Al-Washliyah Medan.

7. Staf LP2M yang turut serta membantu dalam penyelesaian penelitian ini.

\section{DAFTAR PUSTAKA}

[1] A, Yuyun, (2010). 38 Inspirasi Usaha Makanan Minuman Untuk Home Industry. Tangerang : PT. Agro Media Pustaka

[2] Alma, Buchari. 2010. Kewirausahaan untuk Mahasiswa dan Umum. Bandung: Alfabeta.

[3] El-Bantanie, Muhammad Syafei. (2003).Berani Hidup Sukses. Jakarta: Penerbit Republika

[4] Jum'atil dkk, Informasi Kapuas (Jilid 12): 1 Januari 2015 - 31 Desember 2015

[5] Meredith, Geoffrey. G. et al. 2002. Kewirausahaan; Teori dan Praktek. Jakarta: PT. Rineka Cipta.

[6] Novia, Astri dan Natar Adri. 80 Bisnis Sampingan Modal < 5Juta. Jakarta : Penebar Plus

[7] Pertiwi dan Ginting, Yuk Makan Bayam, Jakarta : PT. Gramedia Pustaka Utama

[8] Zimmerer dan Scarborough. (2009). Kewirausahaan dan Manajemen Usaha Kecil. Jakarta : Salemba Empat. 